\title{
The load of heavy metals leaching from grassland in central Ner River valley
}

\author{
Tomasz Bagrowicz ${ }^{1, *}$, Maciej Ziułkiewicz ${ }^{2}$, and Janusz Mazur ${ }^{3}$ \\ ${ }^{1}$ Faculty of Geographical Sciences, University of Łódź, ul. Narutowicza 88, 90-139 Łódź, Poland \\ ${ }^{2}$ Laboratory of Geology, Faculty of Geographical Sciences, University of Łódź, ul. Narutowicza 88, \\ 90-139 Łódź, Poland \\ ${ }^{3}$ Laboratory of Computer and Analytical Techniques, Faculty of Biology and Environmental Protection, \\ University of Łódź, ul. Banacha 12/16, 90-237 Łódź, Poland
}

\begin{abstract}
Polish city in the zone of the main watershed of the country. The watershed zone offered a dense network of small streams, mostly belonging to the Ner River catchment. The use of the Ner River as a collector of industrial sewage caused the accumulation of high amounts of heavy metals in the river sediments and arable land, intensively fertilised with the waters of the Ner River for more than 40 years. Due to the continuation of irrigations in the river valley, water with a substantially lower degree of contamination with organic substance and biogens returns to Ner from the grassland complexes. The objective of the study is the determination whether improvement of water quality subject to circulation within the grassland complexes also concerns heavy metals. The study area covers grassland complexes in the middle section of the Ner River valley, between the weir in Charbice Górne and Jeżew. Due to the variability of acidic-alkaline and oxidation-reduction conditions caused by variable moisture of the soil containing high amounts of allochtonic (post-sewage) organic matter, the observed grassland complexes show liability in terms of retention and release of the analysed metals to Ner. In summer 2018 on the analysed grassland complexes, conditions favouring the emission of all studied metals occurred. This evidences what the discontinuation of irrigation of grassland complexes, previously irrigated with sewage from Łódź, can lead to. The comparison of sites located along the course of the Ner River also provides a complex image of changes in concentrations, with evident fluctuations of metal concentrations.
\end{abstract}

\section{Introduction}

Łódź is the largest Polish city in the zone of the main watershed of the country. This determines a specific system of water supply and sewage management. Due to the lack of a large river that could receive sewage from the rapidly developing industrial city, sewage was directed to the local river network. The watershed zone offered a dense network of small streams, mostly belonging to the Ner River catchment. Over a short time, they became

\footnotetext{
* Corresponding author: bagrowicz.tomasz@gmail.com
} 
degraded, and their recipient began discharging high amounts of sewage far outside the boundaries of Łódź, with a substantial contribution of contaminants originating from industrial plants. Over ten years, the share of industrial sewage was subject to considerable changes, from $51 \%$ in 1965 to $65 \%$ in the years $1985-1990,25 \%$ in 2013 , and $11.6 \%$ currently (2017) [1].

The first urban sewage treatment plant was launched in the first half of the 1930's, more than 100 years after the launch of the first mechanised factory in Łódź equipped with a steam engine. Biological treatment of sewage supplied from the city began in 2002. With the collapse of the textile industry in ŁAM, the city entered another stage of urban planning evolution [2], i.e. from the stage of an industrial city to the stage of a sanitary city. The use of the Ner River as a collector of industrial sewage caused the accumulation of high amounts of heavy metals in the river sediments [3] and arable land, intensively fertilised with the waters of the Ner River for more than 40 years. The content of heavy metals in the soils of the Ner River valley was variable, increasing with the time of irrigation. It was $2-5$ times higher in soils irrigated with sewage in comparison to non-irrigated soils, and particularly depended on the distance from the point of sewage discharge to Ner, content of organic substance in the soil, and depth of the distribution ditch [4].

It is estimated that in the years 1980-1995, over an irrigated area of approximately 4300 ha in the Ner River valley, from 13\% (humid year) to 34\% (very dry year) of sewage discharged from Łódź was used for vegetative irrigations [4]. In the years 1994-1995, in the period of decline of the textile industry in Łódź, the daily load of metals in the outlets of the city's collectors was as follows: $\mathrm{Hg} 0.1 \mathrm{~kg}, \mathrm{Cd} 0.23 \mathrm{~kg}, \mathrm{Cr}\left(6^{+}\right) 2.16 \mathrm{~kg}$, Ni $3.12 \mathrm{~kg}$, $\mathrm{Pb} 5.18 \mathrm{~kg}, \mathrm{Cu} 44.48 \mathrm{~kg}$ [5]. The elimination of industry as the basic source of contamination of the Ner River with heavy metals caused a successive decrease in heavy metal concentrations in the river in the years 1996-2009, as well as an evident reduction of the scale of their seasonal fluctuations [6].

In 1995, granting water permits for water intake from Ner for agricultural irrigations was discontinued due to the strong contamination of the environment [7]. As a result, a process of elimination of the contemporary intensive agricultural production of diary cattle fodder began. The sense of further maintenance of the irrigation system was questioned. It was decided, however, that the system should keep functioning due to the necessity of maintenance of constant humidity conditions in the ground, in order to counteract the remission of contaminants accumulated in the soils to the Ner River, particularly biogens and toxins [4].

Due to the continuation of irrigations in the river valley, water with a substantially lower degree of contamination with organic substance and biogens returns to Ner from the grassland complexes [7]. It is important due to the significance of the river in the region (health resort aspirations of Poddębice) and in other areas (water supply in Poznań). The objective of the study is the determination whether improvement of water quality subject to circulation within the grassland complexes also concerns heavy metals.

\section{Study object}

The Ner River is the largest right-bank tributary of the Upper Warta River. Its total length is $129.5 \mathrm{~km}$, and its catchment occupies an area of $1831 \mathrm{~km}^{2}$. The river begins its course in the south-western suburbs of Łódź. From there, it flows westwards, and further to the north-west. The river runs down from the Łódź Hills, and then through the Łask Plateau and Koło Basin, where it flows into the Warta River. At its mouth, Ner maintains an average flow rate at a level of $13.9 \mathrm{~m}^{3} \cdot \mathrm{s}^{-1}$. In the landscape of the southern suburbs of Łódź, Ner is a small river, with an average flow rate of $0.23 \mathrm{~m}^{3} \cdot \mathrm{s}^{-1}$. Discharge of sewage from the Collective Sewage Treatment Plant in Łódź increases its natural flow rate nine times. An average discharge of 
sewage from the treatment plant in the years 2012-2017 was approximately $2.0 \mathrm{~m}^{3} \cdot \mathrm{s}^{-1}$ $\left(1.77-2.24 \mathrm{~m}^{3} \cdot \mathrm{s}^{-1}\right)$ [8]. Over the years, the amount of sewage discharged to Ner River varied from $1.4 \mathrm{~m}^{3} \cdot \mathrm{s}^{-1}$ (1951) to $4.9 \mathrm{~m}^{3} \cdot \mathrm{s}^{-1}(1992)$.

\section{Material and methods}

The study area covers grassland complexes in the middle section of the Ner River valley, between the weir in Charbice Górne and Jeżew (Fig. 1). The research concerns four neighbouring grassland complexes irrigated by means of the slope method (Table 1). Analyses of waters in the melioration system are conducted on the inlet and outlet for particular complexes, and for comparison on the Pisia River - the only natural tributary on this section of Ner. Sample collection and the accompanying measurements of water reaction, dissolved oxygen (DO) and flow rate (by means of a flow meter or floating object method) is performed once a month (starting from April 2018), on the same day in all the designated measurement-control points following the direction of water flow. Due to the currently implemented programme of meadow irrigation according to individual needs of water companies, the research terms sometimes do not correspond with the conducted cycle of interim irrigation, resulting in lack of information in certain terms. In such circumstances, measurements and sample collection are performed in the Ner channel in direct vicinity of the irrigation ditch, treating the determined hydrochemical conditions as potential and not actual.

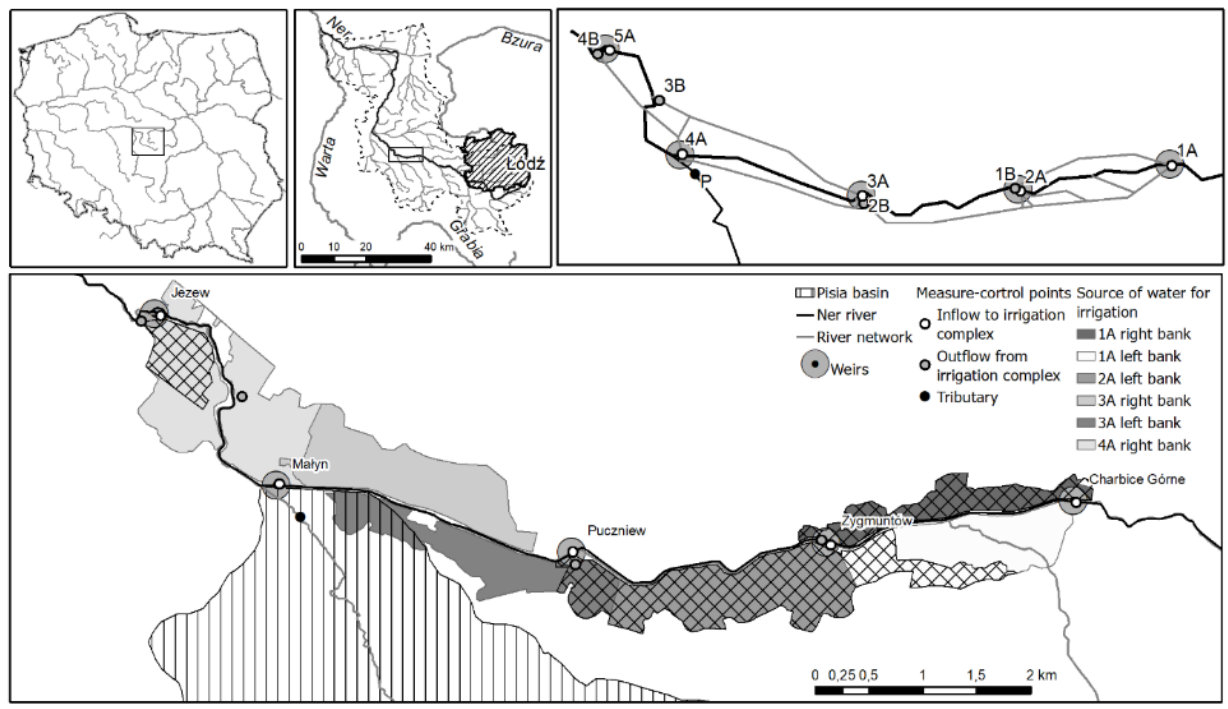

Fig. 1. Scheme of the circulation of water used for irrigation in the drainage system in the Ner River Valley and location of the balance areas.

Based on the obtained measurement of water flow rate on the inlet an outlet from the grassland complex, the load of the supplied and discharged heavy metals is determined. The scope of the chemical analysis includes the following heavy metals: $\mathrm{Cd}, \mathrm{Cr}, \mathrm{Cu}, \mathrm{Fe}, \mathrm{Mn}, \mathrm{Ni}$, $\mathrm{Pb}, \mathrm{Zn}$. The collected water samples are filtered in situ through a membrane filter $0.45 \mu \mathrm{m}$ and fixed with $\mathrm{HNO}_{3}$. Determinations are performed at the Laboratory of Computer and Analytical Techniques of the Faculty of Biology and Environmental Protection of the University of Łódź by means of the method of atomic absorption spectrometry with electromagnetic atomisation, and method of flame atomic absorption spectrometry. 
Table 1. Surface areas of irrigated grassland complexes subject to the study $\left[\mathrm{km}^{2}\right](A-i n f l o w$ to irrigation complex, B- outflow from irrigation complex).

\begin{tabular}{|c|c|c|c|c|c|c|c|}
\hline \multirow{3}{*}{\multicolumn{2}{|c|}{ Complex }} & \multicolumn{6}{|c|}{ Source of water for irrigation: } \\
\hline & & \multicolumn{2}{|c|}{ Weir Charbice Górne } & \multirow{2}{*}{$\begin{array}{c}\text { Weir } \\
\text { Zygmuntów }\end{array}$} & \multicolumn{2}{|c|}{ Weir Puczniew } & \multirow{2}{*}{$\begin{array}{l}\text { Weir } \\
\text { Małyń }\end{array}$} \\
\hline & & Left bank & Right bank & & Left bank & Right bank & \\
\hline \multirow{2}{*}{1} & $\mathrm{~A}$ & & 0.57 & & & & \\
\hline & B & & 0.57 & & & & \\
\hline \multirow{2}{*}{2} & A & & & 1.16 & & & \\
\hline & B & 0.35 & & 1.16 & 0.22 & & \\
\hline \multirow{2}{*}{3} & $\mathrm{~A}$ & & & & & 1.11 & \\
\hline & $\mathrm{B}$ & & & & & 0.89 & 0.39 \\
\hline \multirow{2}{*}{4} & $\mathrm{~A}$ & & & & & & 1.73 \\
\hline & $\mathrm{B}$ & & & & & & 0.34 \\
\hline
\end{tabular}

Source: Own elaboration

\section{Results}

Meteorological data for station IMGW Łódź-Lublinek, referred to the multi-annual characteristics [9], present 2018 as a very warm year with a precipitation total below the multi-annual average. Mean annual temperature in 2018 exceeded the highest mean annual value from the multi-annual period by $0.3^{\circ} \mathrm{C}$. The precipitation total was $510 \mathrm{~mm}$, and was lower than the mean annual total from the multi-annual period by $65 \mathrm{~mm}$. The highest contribution of atmospheric precipitation was observed in July and October: $21 \%$ and 18\% of annual precipitation, respectively. A total of 133 days with precipitation occurred in 2018 $(>0.1 \mathrm{~mm})$. The value is 34 days lower than the multiannual average. The Ner River valley in a part of which the research was conducted shows the index of climatic precipitation deficit in the period from April to October at a level from $-120 \mathrm{~mm}$ to $-80 \mathrm{~mm}$ [10].

Water flow on the inlet and outlet of the irrigation system of the grassland complexes is presented in Fig. 2. Only one of the studied complexes (Zygmuntów) was irrigated regularly. In Charbice, irrigations were discontinued in autumn of the same year. In Puczniew, introduction of the waters of the Ner River to fields was discontinued based on the decision of the property owner, and in Małyn water is introduced to the fields only in the scope of interim needs of farmers, because in their opinion, Ner already carries low amounts of fertiliser substances along this section.

Water reaction at sites representing river waters on the inlet to distribution ditches varied from 6.42 to 7.67. On outlets from grassland complexes reaction in a range of 6.53-7.50 was recorded. Therefore, weakly acidic, neutral, and weakly alkaline waters circulated in the system of valley irrigation. The waters of Pisia were stronger alkaline than in the Ner valley, because their reaction was within the range from 7.26 to 8.16 .

Oxygen saturation of waters introduced to the grasslands varied from $12 \%$ to $81 \%$, averaging $60 \%$. In waters flowing out of the grasslands to the Ner River, the determined oxygen saturation showed a narrower range, namely $25 \%-53 \%$, averaging $36 \%$.

The comparison of the statistical characteristics of recorded concentrations of heavy metals at sites representing the entrance and exit from the irrigation system reveals the mosaic character of changes, expressed in the quartile range and median (Fig. 3). A decrease in concentrations of $\mathrm{Mn}$ and an increase in Ni was observed on all complexes. A reduction of concentrations of all analysed metals with the exception of Mn occurred on complex Zygmuntów. An increase in concentrations of $\mathrm{Cu}$ and $\mathrm{Zn}$ was recorded on the remaining complexes. 
a.

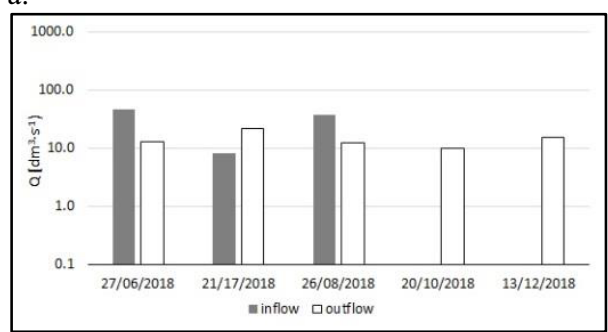

c.

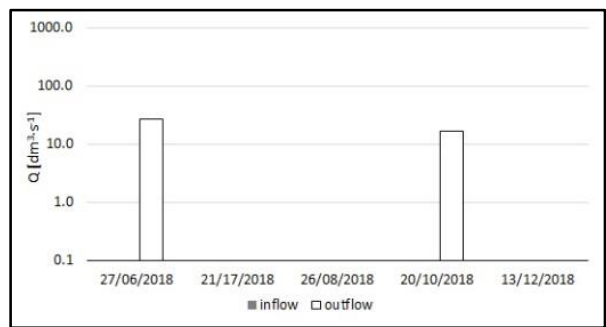

b.

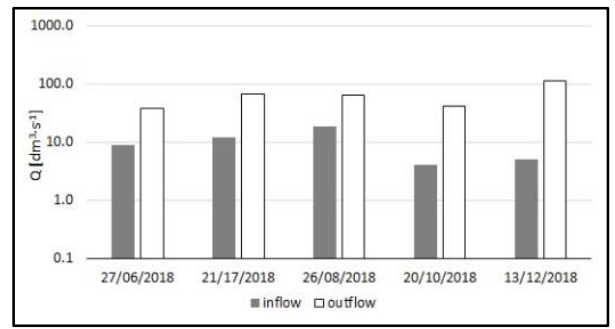

d.

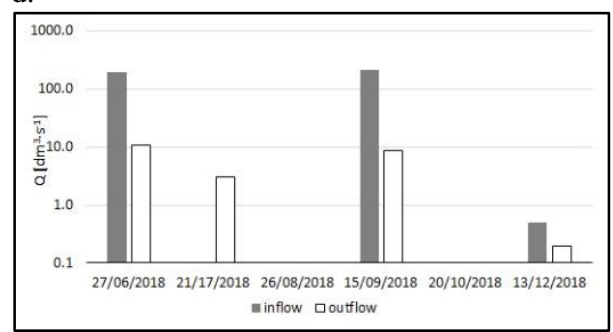

Fig. 2. Comparison of the amount of waters flowing in and out of grassland complexes during the hydrochemical research: a/ Charbice, b/ Zygmuntów, c/ Puczniew, d/ Małyń.

The comparison of sites located along the course of the Ner River also provides a complex image of changes in concentrations, with evident fluctuations of metal concentrations. It can be observed, however, that Fe and Mn gradually decreased to the mouth of Pisia, and then increased. Concentrations of $\mathrm{Cu}$ and $\mathrm{Pb}$ increased to Puczniew, and the decreased. An evident increase in the median of $\mathrm{Cd}$ and $\mathrm{Cr}$ concentrations was recorded in Małyń. The balanced unitary load of metals, calculated based on the obtained concentrations and results of water flow measurement on the inlet and outlet from the grassland complexes is presented in Table 2.

$\mathrm{Mn}$ is released from the analysed meadow complexes the most frequently. The remaining metals are released from practically all complexes in summer, and from Zygmuntów and Małyń also in winter. Due to the number of cases of occurrene of positive results of balancing of loads, metals are supplied to Ner from the Charbice complex the most seldom, more frequently from Małyń, and the most frequently from Zygmuntów. 

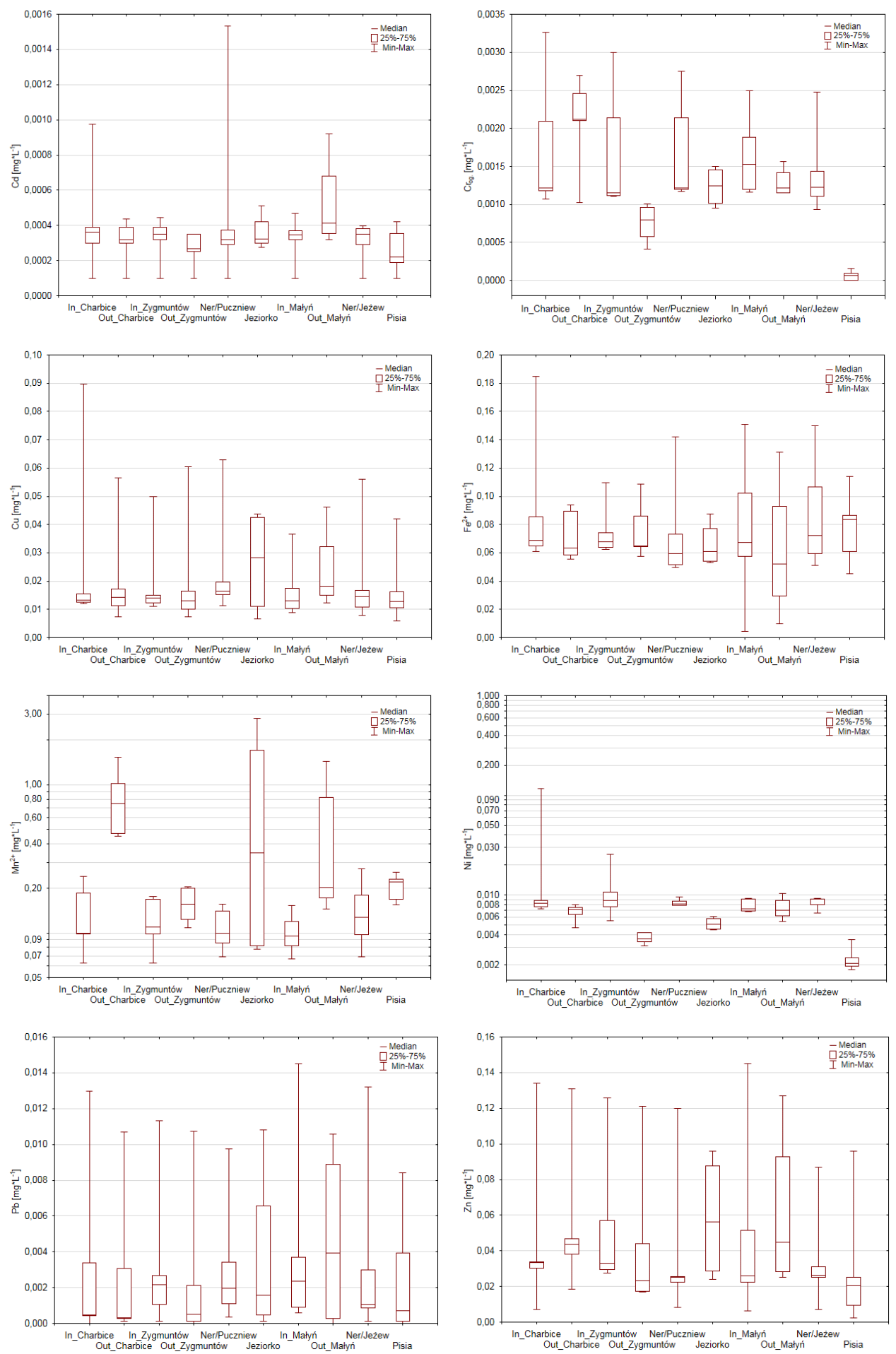

Fig. 3. Ranges of concentrations of metals at the study sites. 
Table 2. Balance of unitary loads of metals in irrigated land of grassland complexes. The calculations are based on instantaneous measurements.

\begin{tabular}{|c|c|c|c|c|c|c|c|c|}
\hline \multirow{2}{*}{ Complex / month } & \multicolumn{9}{|c|}{ Unitary load $\left[\mathbf{g}^{-\mathbf{1}} \mathbf{k m}^{-\mathbf{2}}\right]$} \\
\cline { 2 - 9 } & $\mathrm{Cd}$ & $\mathrm{Cr}$ & $\mathrm{Cu}$ & $\mathrm{Fe}$ & $\mathrm{Ni}$ & $\mathrm{Mn}$ & $\mathrm{Pb}$ & $\mathrm{Zn}$ \\
\hline Charbice / VI 2018 & -0.50 & -6.17 & -71.52 & -341.42 & -42.52 & 204.40 & -2.63 & -171.82 \\
\hline Charbice / VII 2018 & 0.83 & 5.42 & 30.39 & 122.48 & 14.36 & 4792.97 & 1.01 & 111.68 \\
\hline Charbice / VIII 2018 & -1.16 & -1.58 & -47.70 & -182.50 & -35.73 & 1008.33 & -2.21 & -112.97 \\
\hline Charbice / X 2018 & -0.71 & -6.77 & -21.66 & -422.17 & -16.26 & 1234.27 & -5.75 & 36.21 \\
\hline Charbice / XII 2018 & -1.99 & -0.32 & -146.34 & -129.21 & -339.06 & 269.96 & -15.48 & -114.59 \\
\hline Zygmuntów / VI 2018 & -0.11 & -2.62 & -17.53 & -82.07 & -16.86 & 72.15 & -1.82 & -54.01 \\
\hline Zygmuntów / VII 2018 & 0.31 & 1.75 & 35.30 & 196.23 & 2.12 & 435.67 & -0.95 & 35.26 \\
\hline Zygmuntów / VIII 2018 & 0.09 & -1.66 & -13.83 & 142.46 & -17.47 & 297.25 & -0.60 & -54.09 \\
\hline Zygmuntów / X 2018 & 0.24 & -2.51 & 6.74 & -85.16 & -2.23 & 125.32 & 0.36 & 67.26 \\
\hline Zygmuntów / XII 2018 & 0.52 & 3.28 & 251.02 & 278.38 & -92.94 & 370.49 & 47.42 & 546.33 \\
\hline Małyń / VI 2018 & 0.67 & 1.06 & 16.65 & 18.26 & 2.47 & 316.08 & 0.44 & 24.69 \\
\hline Małyń / VII 2018 & -0.12 & -0.23 & 1.69 & -16.08 & -2.55 & 977.16 & -1.53 & 2.47 \\
\hline Małyń / VIII 2018 & -0.36 & -1.18 & -10.11 & -73.19 & -7.13 & -66.08 & -0.91 & -28.37 \\
\hline Małyń / X 2018 & -0.33 & -2.46 & -13.27 & -148.73 & -6.67 & -81.13 & -3.12 & -6.09 \\
\hline Małyńn / XII 2018 & 0.02 & 0.05 & 2.16 & 2.23 & 0.48 & 6.90 & 0.46 & 5.70 \\
\hline
\end{tabular}

Notice: positive value means release to the Ner River, negative value means retention in soil

\section{Discussion and conclusions}

Concentrations of heavy metals in the waters of the Ner River show considerable variability - from values characteristic of natural waters to those of polluted waters. Lead concentration in non-polluted rivers is several $\mathrm{mg} \cdot \mathrm{dm}^{-3}$. Concentrations of lead and its compounds in the Warta River in Dobrowa, above the mouth of the Ner River, are $0.0047 \mathrm{mg} \cdot \mathrm{dm}^{-3}$, and cadmium and its compounds $0.0005 \mathrm{mg} \cdot \mathrm{dm}^{-3}$, respectively. They are values within the range of class I of water cleanliness. In Koło, values of lead and cadmium point to class III and IV of waters, respectively [11]. The adopted natural content of zinc in river water was $0.01 \mathrm{mg} \cdot \mathrm{dm}^{-3}$. The waters of Ner reach more than 5 times higher concentrations, but the values are generally within the range of values of the waters of the Oder River catchment which are estimated as $0.03-0.165 \mathrm{mg} \cdot \mathrm{dm}^{-3}$, whereas higher concentrations are recorded in the waters of the Upper Silesian Agglomeration [12]. Chromium concentration in non-polluted waters is $0.0005 \mathrm{mg} \cdot \mathrm{dm}^{-3}$. The minimum recorded concentrations are twice as high, although they do not exceed values for class I of water quality [13].

Copper, zinc, nickel, and manganese concentrations are higher than the values recorded in the Jangcy River, where they are within the following ranges: $0.0015-0.0231 \mathrm{mg} \mathrm{Cu} \cdot \mathrm{dm}^{-3}, 0.0013-0.0457 \mathrm{mg} \mathrm{Zn} \cdot \mathrm{dm}^{-3}, 0.0004-0.0063 \mathrm{mg} \mathrm{Ni} \cdot \mathrm{dm}^{-3}$, and $0.077-0.5 \mathrm{mg} \mathrm{Mn} \cdot \mathrm{dm}^{-3}$. Concentrations in waters used for irrigations in China show very high fluctuations, and can exceed the values recorded in the Ner River multiple times: $\mathrm{Cd}^{-} \quad 0.0002-3.45 \mathrm{mg} \cdot \mathrm{dm}^{-3}, \quad \mathrm{Cr}^{-} \quad 0.0003-4.08 \quad \mathrm{mg} \cdot \mathrm{dm}^{-3}, \quad \mathrm{Mn}^{-} \quad 0.251 \mathrm{mg} \cdot \mathrm{dm}^{-3}$, $\mathrm{Ni}^{-} 0.007 \mathrm{mg} \cdot \mathrm{dm}^{-3}, \mathrm{~Pb}^{-} 0.0005-6.86 \mathrm{mg} \cdot \mathrm{dm}^{-3}, \mathrm{Zn}^{-} 0.05-51 \mathrm{mg} \cdot \mathrm{dm}^{-3}$ [14]. In the El Saf Region in Egypt, sewage waters used for irrigations also show higher concentrations of heavy metals: $0.004-0.08 \mathrm{mg} \cdot \mathrm{dm}^{-3}$ cadmium, $0.02-0.28 \mathrm{mg} \cdot \mathrm{dm}^{-3}$ lead, and $0.001-0.03 \mathrm{mg} \cdot \mathrm{dm}^{-3}$ nickel [15].

Maximum values of $\mathrm{Ni}, \mathrm{Cu}$, and $\mathrm{Mn}$ concentrations exceed values recorded in the rivers of the Silesian Voivodeship: Kłodnica, Bytomka, Czerniawka, or Biała Przemsza [16]. Total load of heavy metals discharged from the Oder River to the Baltic Sea in 2009 includes: zinc - $0.48 \mathrm{~kg} \cdot \mathrm{km}^{-2} \cdot \mathrm{year}^{-1}$, translating into $49.1 \mathrm{t} \cdot \mathrm{year}^{-1}$, copper $-0.27 \mathrm{~kg} \cdot \mathrm{km}^{-2} \cdot \mathrm{year}^{-1}$ i.e. $27.22 \mathrm{t} \cdot \mathrm{year}^{-1}$, nickel $-0.23 \mathrm{~kg} \cdot \mathrm{km}^{-2} \cdot$ year $^{-1}$ i.e. $23.88 \mathrm{t} \cdot \mathrm{year}^{-1}$, and cadmium $0.01 \mathrm{~kg} \cdot \mathrm{km}^{-2} \cdot$ year $^{-1}$ i.e. $0.67 \mathrm{t} \cdot \mathrm{year}^{-1}[17]$. 
The range of $\mathrm{pH}$ recorded in the waters circulating between the inlet and outlet of the irrigation system is neutral and weakly alkaline. Assuming the occurrence of oxygenation conditions at an average saturation of the waters at a level of $60 \%$, such reaction should cause geochemical immobility of practically all the analysed metals. Especially that the valley environment is abundant in organic matter, loamy minerals, silica, iron and manganese hydroxides, fulfilling the role of effective sorbents [18-20]. Waters flowing out of the grasslands show a somewhat lower oxygen saturation - on a level of $36 \%$ (min. $25 \%$ ). This suggests the impact of the gley environment of valley soils, developed based on alluvial and sewage sediments. In such conditions, $\mathrm{Fe}$ and $\mathrm{Mn}$ become mobile water migrants [20].

Due to the variability of acidic-alkaline and oxidation-reduction conditions caused by variable moisture of the soil containing high amounts of allochtonic (post-sewage) organic matter, the observed grassland complexes show liability in terms of retention and release of the analysed metals to Ner. The conditions occurring in the Zygmuntów complex deserve particular attention. They favour emission of $\mathrm{Cd}$ as well as $\mathrm{Cu}, \mathrm{Fe}$, and $\mathrm{Zn}$. Cadmium and the remaining aforementioned metals are effectively sorbed by iron hydroxides $[18,19]$. The disappearance of hydroxides, suggested by the release of iron in summer and winter, led to the gradual mobilisation of Cd, very hazardous for living organisms [19].

In summer 2018 on the analysed grassland complexes, conditions favouring the emission of all studied metals occurred. During hot and dry weather, a decrease in the groundwater level occurred - oxygenation of the uppermost parts of the saturation zone - oxygenation of the deposited sulphates - acidification and mobilisation of metals effectively migrating in the acidic environment. This evidences what the discontinuation of irrigation of grassland complexes, previously irrigated with sewage from Łódź, can lead to. In winter 2018, the release also occurred from complexes Zygmuntów and Małyń. This requires further investigation.

From the point of view of the quality of river waters, retention of toxic metals in irrigated land is positive. Final treatment of Ner occurs there. The river currently predominantly carries contaminants mobilised from channel bottom sediments.

The progressing accumulation of heavy metals in the grasslands excludes them from the production of safe fodders.

\section{References}

1. Raport o stanie środowiska $w$ województwie tódzkim. Na podstawie badań przeprowadzonych w ramach Państwowego Monitoringu Środowiska w 2017 r., 2018. (Wojewódzki Inspektorat Ochrony Środowiska w Łodzi, Łódź)

2. S.S. Kaushal, W.H. McDowell, W.M. Wollheim, T.A. Newcomer-Johnson, P.M. Mayer, K.B. Belt, M.J. Pennino, Water 7, 8 (2015)

3. I. Bojakowska, Wplyw odprowadzania ścieków na akumulację metali ciężkich w osadach wybranych rzek Polski (Państwowy Instytu Geologiczny, Warszawa, 1995)

4. J. Mosiej, Przyrodniczo- techniczne uwarunkowania gospodarowania woda $w$ dolinie rzeki Ner (SGGW, Warszawa, 1999)

5. J. Diehl, Założenia polityki ekologicznej miasta Łodzi (Urząd Miasta Łodzi, Łódź, 1997)

6. Wyniki monitoringu wód powierzchniowych $w$ ramach Państwowego Monitoringu Środowiska $w$ latach 1996-2009 (Wojewódzki Inspektorat Ochrony Środowiska $\mathrm{w} \quad$ Łodzi. https://www.wios.lodz.pl/Wyniki_badan_wod_powierzchniowych,154 updated 2018.07.02, visited 2018.11.21)

7. A. Matczak, Ocena możliwości $i$ skutków środowiskowych doczyszczania wód ściekowych odpływających z oczyszczalni ścieków w Lodzi poprzez nawodnienia i inne 
przedsięwzięcia ochronne [Typescript of the diploma thesis] (SGGW-KKŚiM, Warszawa, 1998)

8. http://www.gos.lodz.pl/dla-studentow/oczyszczalniadane-technologiczne/updated 2018.03.02, visited 2019.01.15.

9. A. Podstawczyńska, Temperatura powietrza i opady atmosferyczne w regionie łódzkim w ostatnim stuleciu (Bogucki Wydawnictwo Naukowe, Poznań, 2010)

10. A. Ciepielowski, Podstawy gospodarowania woda (SGGW, Warszawa, 1999)

11. Stan wód Warty na terenie województwa wielkopolskiego w latach 1999-2009 (Biblioteka Monitoringu Środowiska, Poznań, 2010)

12. Biuletyn: Ocena jakości powierzchniowych wód plynacych $w$ punktach pomiarowokontrolnych województwa śląskiego w 2001 roku. Zlewnia Odry (Inspekcja Ochrony Środowiska, Śląski Wojewódzki Inspektorat Ochrony Środowiska w Katowicach, Katowice, 2002)

13. Rozporzadzenie Ministra Środowiska w sprawie klasyfikacji dla prezentowania stanu wód powierzchniowych i podziemnych, sposobu prowadzenia monitoringu oraz sposobu interpretacji wyników i prezentacji stanu tych wód (Dz.U.2004.32.284)

14. S. Cheng, Environ. Sci. Pollut. R. 10, 3 (2003)

15. H. El Azab, A. Afify, M. Soliman, EJRS 18, 2 (2015)

16. W. Nocoń, Rola zawiesin $w$ transporcie metali ciężkich $w$ plynacych wodach powierzchniowych [Typescript of the diploma thesis] (Politechnika Śląska Wydział Inżynierii Środowiska i Energetyki, Gliwice, 2011)

17. Stan czystości rzek na podstawie wyników badań wykonywanych $w$ ramach państwowego monitoringu środowiska w latach 2007-2009 (Biblioteka Monitoringu Środowiska, Warszawa, 2010)

18. C. A. J Domenico, D. Postma, Geochemistry, groundwater and pollution (A. A.Ballkema, Rotterdam, 1996)

19. I. Bojakowska, Wpływ czynnika antropogenicznego na procesy geochemiczne w powierzchniowych warstwach litosfery (Państwowy Instytut Geologiczny, Warszawa, 1994)

20. F.R. Siegel, Environmental Geochemistry of Potentially Toxic Metals (Springer-Verlag, Berlin/New York, 2002) 